\title{
32. BENTHIC FORAMINIFER ASSEMBLAGES IN NEOGENE LAMINATED DIATOM OOZE DEPOSITS IN THE EASTERN EQUATORIAL PACIFIC OCEAN (SITE 844) ${ }^{1}$
}

\author{
S.C. King, ${ }^{2}$ A.E.S. Kemp ${ }^{2}$ and J.W. Murray ${ }^{3}$
}

\begin{abstract}
Several widely correlatable intervals of laminated Thalassiothrix diatom mat deposits occur in Neogene sediments recovered from the eastern equatorial Pacific Ocean. The presence of laminated sediments in extensive areas of the deep open ocean floor raises fundamental questions concerning the cause of preservation of the laminations and the nature of the benthic environment during episodes of mat deposition. Traditional explanations for the preservation of laminations have centered on restriction of dissolved oxygen. Studies of benthic foraminifers through the laminated intervals show no evidence for an increase in absolute or relative abundance of species characteristic of a low oxygen environment, but rather a decrease in relative abundance of infaunal forms attesting to the impenetrability of the diatom meshwork formed by the interlocking Thalassiothrix frustules. These results support evidence from coring of the high tensile strength of the Thalassiothrix laminations suggesting that the diatom meshwork was of sufficient tensile strength and impenetrability to suppress infaunal benthic activity. Comparison of the relative abundances of foraminifers in the enclosing "background" sediment of foraminifer nannofossil ooze and the laminated diatom oozes shows that some epifaunal species (e.g., Cibicides spp.) increase in relative abundance within the laminated sediment, whereas others (e.g., Epistominella exigua) show a marked decrease in relative abundance. Other species show more complex changes in abundance related to the occurrence of the laminated sediments, which may indicate a combination of controls that include the physical nature of the substrate and the amount of organic flux.
\end{abstract}

\section{INTRODUCTION}

The discovery of extensive and widely correlatable intervals of laminated diatom ooze in the eastern equatorial Pacific Ocean has been one of the most exciting results of Leg 138 drilling (Kemp and Baldauf, 1993). These remarkable sediments record periods of massive flux of diatom mats to the sea floor, at rates of deposition exceeding $100 \mathrm{~cm} / \mathrm{ka}$. When laminated diatom ooze was initially recovered at Site 844, it was thought that preservation of laminations within the mat deposits might be the result of localized low concentrations of dissolved oxygen. However, when mat deposits were recovered from additional, geographically widespread sites, it became obvious that local anoxia could not be sustained on a regional scale on an open ocean floor where oxygen was free to diffuse. Observations on benthic foraminifers within the laminated diatom mat deposits further suggested the presence of normal dissolved oxygen levels. We wanted to test the possibility of the occurrence of low levels of dissolved oxygen, and to deduce other paleoenvironmental parameters.

New, long time-series measurements of flux to the deep sea have shown that episodic fluxes of organic matter make up a major proportion of the material responsible for sustaining benthic communities (Smith et al., 1992), including benthic foraminifers (Gooday and Lambshead, 1989). Furthermore, recent sediment-trap data have highlighted the significance of diatom mats as periodic agents of rapid flux to the seafloor (Sancetta et al., 1991). The recovery of extensive diatom mat deposits from the eastern equatorial Pacific Ocean confirms that massive fluxes of diatoms have occurred regularly in the deep sea and provides the opportunity to use newly developed understanding of the influence of microhabitat on benthic foraminifers as an indicator of depositional environment (Corliss, 1985).

' Pisias, N.G., Mayer, L.A.. Janecek, T.R. Palmer-Julson, A.. and van Andel, T.H. (Eds.). 1995. Proc. ODP Sci. Results, 138: College Station TX (Ocean Drilling Program).

2 Department of Oceanography, University of Southampton, Southampton SO9 $5 \mathrm{NH}$. United Kingdom.

${ }^{3}$ Department of Geology, University of Southampton, Southampton SO9 5NH, United Kingdom.
We report the results of a preliminary study of benthic foraminifer assemblages at Site $844\left(7^{\circ} 55.278^{\prime} \mathrm{N}, 90^{\circ} 28.848^{\prime} \mathrm{E}\right.$; present water depth, $3415 \mathrm{~m}$ ). The aim of this pilot study was to assess changes in the relative abundance of benthic foraminifers through an interval of laminated diatom ooze of late middle Miocene age. Benthic foraminifers also were analyzed from the enclosing foraminifer nannofossil ooze below and above the laminated sediment.

\section{Previous Studies of Benthic Foraminifers}

The distribution of benthic foraminifers in the present-day Pacific Ocean has been studied by Boltovsky (1976) and Resig (1981) and is well documented in Murray (1991). Herguera (1992) showed that during glacial to post-glacial stages, the abundance of benthic foraminifers was related to surface-water productivity. Upper Eocene to Holocene benthic foraminifers from the equatorial Pacific Ocean were studied by Thomas (1985), while a Miocene record was produced by Woodruff and Savin (1985). A record of benthic foraminifers from the Holocene to the early Eocene of the Peru margin was developed by Resig (1990) that included sites containing middle Miocene bathyal assemblages.

Information about the microhabitat of Holocene benthic foraminifers from the coastal areas of the Pacific Ocean was provided by Bandy and Rodolfo (1964), McCorkle et al. (1990), and Mackensen and Douglas (1989). From the study of the distribution of living foraminifers in sediments, we know, for example, that Uvigerina sp. is a shallow infaunal species (at a depth of 0-2 cm), Melonis sp. is an intermediate to deep infaunal species (at a depth of 1-4 cm), while Gyroidina sp. is an epifaunal form. From work in the Norwegian Sea, Corliss and Chen (1988) classified benthic foraminifers on morphological characters and gave their probable microhabitat.

Relative abundances of benthic foraminifers such as Uvigerina peregrina have been used to document changes in oxygen levels in the deep sea (Streeter and Shackleton, 1979), but subsequent research (Miller and Lohmann, 1982; Corliss et al., 1986; Lutze and Coulbourn, 1984) has indicated that higher organic carbon content, rather than low oxygen, may be the main controlling factor. Other genera, such as Bolivina, have been more consistently identified as low oxygen indicators (Boltovskoy, 1976; Mullins et al., 1985), although it has been 
suggested that higher organic carbon content may also be the dominant ecological influence (B. Corliss, pers. comm., 1992). The use of individual species as indicators of past pulsed fluxes of phytodetritus has been developed since the discovery of the association of certain species with this material in present-day sediments (Gooday and Lambshead, 1989).

\section{METHODS AND SAMPLING}

Samples $\left(15 \mathrm{~cm}^{3}\right)$ were taken from an intermittently laminated interval in Core 138-844C-8H (age, ca. $11 \mathrm{Ma}$, Kemp and Baldauf, 1993; Kemp et al., this volume). Within this interval, samples were taken from laminated diatom ooze and interbedded horizons of nannofossil diatom and diatom nannofossil oozes. Samples also were taken from the adjacent nonlaminated nannofossil foraminifer and diatom nannofossil oozes above and below the laminated interval to illustrate the comparison with background sedimentation. Descriptions of individual sediment samples are given in Table 1, and sample lithology has been schematically presented in Figures 1 through 3 . Sedimentology and microfacies of the laminated diatom ooze are discussed in detail in Pearce et al. (this volume).

All samples were dried, soaked, and washed through a $63 \mu \mathrm{m}$ sieve; the size fraction larger than $63 \mu \mathrm{m}$ was analyzed for benthic foraminifers. A minimum of 220 individual benthic foraminifers was picked from each sample, from which relative abundance of individual species was calculated. We used the morphotype classification of Corliss and Chen (1988) (Tables 2 and 3). This provides a clear method for defining foraminifers microhabitats that agrees with the later Pacific Ocean deep-sea studies of McCorkle et al. (1990). Species diversity was calculated using the Fisher alpha index (Fisher et al., 1943).

\section{RESULTS}

Changes in the relative abundances of major benthic foraminifers species are shown in Figures 1 and 2. Dominant epifaunal species include Cibicides spp., Epistominella exigua, Alabaminella weddel-
Table 1. Sample depths and sediment description (Core 138-844C-8H).

\begin{tabular}{lll}
\hline $\begin{array}{c}\text { Core, section, } \\
\text { interval }(\mathrm{cm})\end{array}$ & $\begin{array}{c}\text { Depth } \\
\text { (mbsf) }\end{array}$ & \multicolumn{1}{c}{$\begin{array}{c}\text { Description } \\
\text { of sediment }\end{array}$} \\
\hline 138-844C- & & \\
$8 \mathrm{H}-1,50-52$ & 66.60 & Homogeneous foraminifer nannofossil ooze \\
$8 \mathrm{H}-1,130-132$ & 67.40 & Homogeneous foraminifer nannofossil ooze \\
$8 \mathrm{H}-2,55-57$ & 68.15 & Bioturbated diatom nannofossil ooze \\
$8 \mathrm{H}-2,138-140$ & 68.98 & Laminated diatom ooze \\
$8 \mathrm{H}-3,18-20$ & 69.28 & Laminated diatom ooze \\
$8 \mathrm{H}-3,64-66$ & 69.74 & Bioturbated diatom nannofossil ooze \\
$8 \mathrm{H}-3,120-122$ & 70.30 & Laminated diatom ooze \\
$8 \mathrm{H}-4,2-4$ & 70.62 & Laminated diatom ooze \\
$8 \mathrm{H}-4,70-72$ & 71.30 & Bioturbated nannofossil diatom ooze \\
$8 \mathrm{H}-4,120-122$ & 71.80 & Laminated diatom ooze \\
$8 \mathrm{H}-5,5-7$ & 72.15 & Bioturbated nannofossil diatom ooze \\
$8 \mathrm{H}-5,44-46$ & 72.54 & Homogeneous foraminifer \\
$8 \mathrm{H}-5,85-87$ & 74.40 & Homogeneous foraminifer nannofossil ooze \\
$8 \mathrm{H}-5,130-132$ & 74.40 & Homogeneous foraminifer nannofossil ooze \\
& & \\
\hline
\end{tabular}

lensis, Gyroidina spp., and Eponides spp.. These species are present throughout the length of the section studied, however, their relative abundances vary markedly between sediment types; the average relative abundance within each lithology is shown in Tables 4 and 5 .

Within the homogeneous nannofossil foraminifer ooze $(\mathrm{H}) A$. weddellensis makes up less than $10 \%$ of the assemblage. This species has the greatest relative abundance in the laminated (L) and bioturbated (B) diatom ooze samples; however, in both lithologies a large range of values can be seen $(0.5-29 \%$; Table 4$)$. A. weddellensis shows a marked increase ( $>20 \%$ ), from the homogeneous nannofossil foraminifer ooze at the base of the section to the intermittently laminated interval (Fig. 1; 73-71 mbsf). The relative abundance decreases toward the top of the intermittently laminated interval to a level only $5 \%$ on average greater than the abundance in the unlaminated sections (Table 4). E. exigua has the highest relative abundance in the homogeneous nannofossil foraminifer ooze (Table 4).

Eponides spp. are most abundant in the laminated diatom ooze showing wide variation (Table 4). The upper part of the intermittently laminated interval has the greatest abundance (Fig. 1). In the homog-

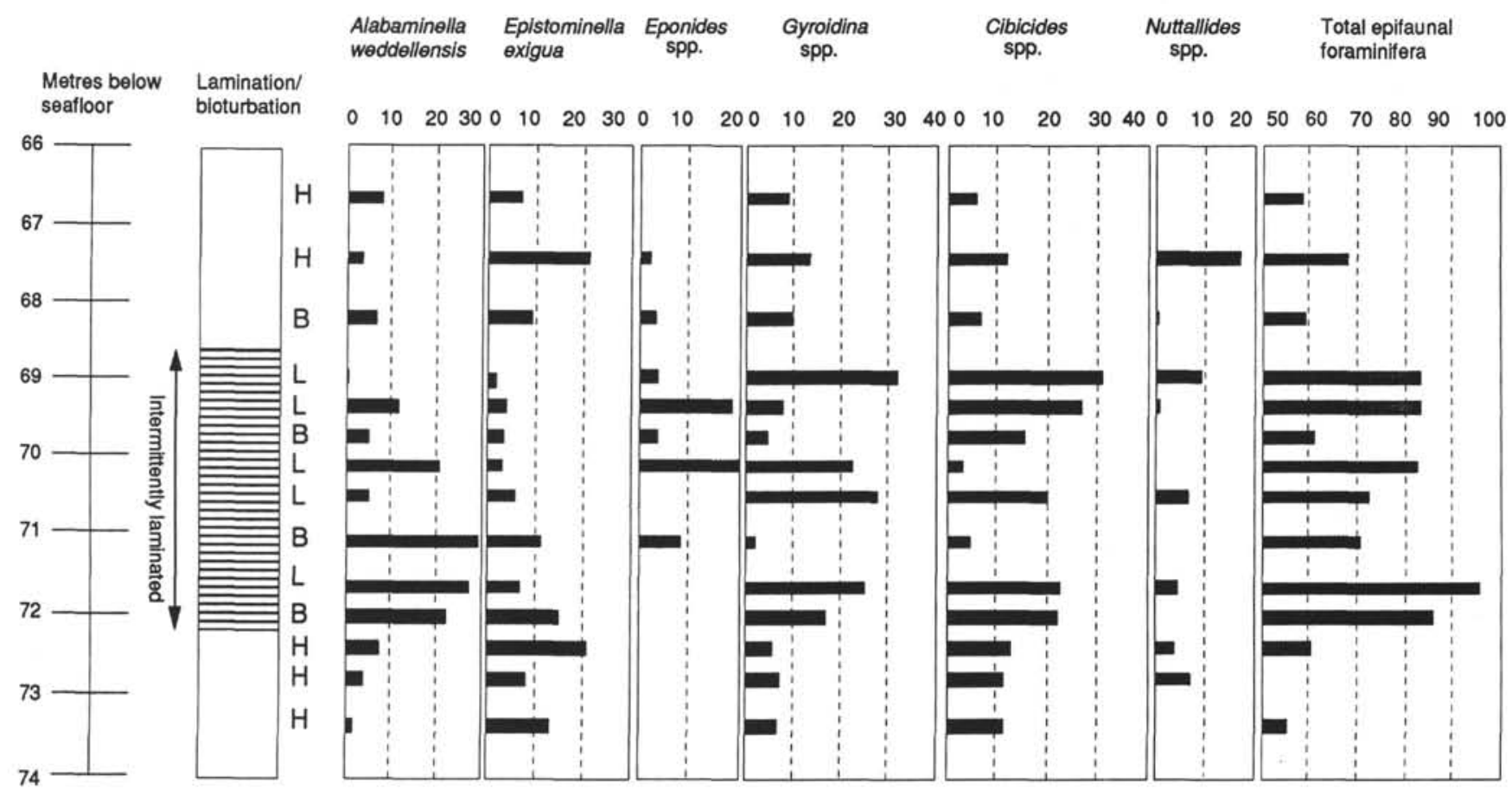

Figure 1. Hole 844C. Relative abundances of epifaunal benthic foraminifers $(\%)$. Laminated diatom ooze $=\mathrm{L}$; bioturbated diatom nannofossil ooze = B; and homogeneous nannofossil foraminifer ooze $=\mathrm{H}$; see Table 1. Note that B contains a varying quantity of diatom mat fragments, whereas the laminated diatom ooze, L contains $100 \%$ mats, and $\mathrm{H}$ contains no trace of mats. 
Table 2. Epifaunal foraminifer morphotypes (Corliss and Chen, 1988).

\begin{tabular}{cccc}
\hline \multicolumn{3}{c}{ Epifaunal } \\
\hline $\begin{array}{c}\text { Round } \\
\text { trochospiral }\end{array}$ & $\begin{array}{c}\text { Plano-convex } \\
\text { trochospiral }\end{array}$ & Milioline & \multicolumn{1}{c}{$\begin{array}{c}\text { Biconvex } \\
\text { trochospiral }\end{array}$} \\
\hline Gyroidina & $\begin{array}{l}\text { Cibicides } \\
\text { Cibicidoides } \\
\text { Anomalina glohulosa }\end{array}$ & $\begin{array}{l}\text { Pyrgo } \\
\text { Sigmoilina }\end{array}$ & $\begin{array}{l}\text { Alahaminella weddellensis } \\
\text { Epistominella } \\
\text { Eponides } \\
\text { Laticarinina patperata } \\
\text { Lenticulina } \\
\text { Oridorsalis umbonatus } \\
\text { Nuttallides }\end{array}$ \\
\end{tabular}

Table 3. Infaunal foraminifer morphotypes (Corliss and Chen, 1988).

\begin{tabular}{|c|c|c|c|}
\hline \multicolumn{4}{|c|}{ Infaunal } \\
\hline $\begin{array}{l}\text { Round } \\
\text { planispiral }\end{array}$ & $\begin{array}{l}\text { Flattened } \\
\text { ovoid }\end{array}$ & $\begin{array}{c}\text { Tapered } \\
\text { and cylindrical }\end{array}$ & Spherical \\
\hline $\begin{array}{l}\text { Elphidium } \\
\text { Melonis } \\
\text { Nonion } \\
\text { Nonionella } \\
\text { Pullenia }\end{array}$ & $\begin{array}{l}\text { Cassidulina } \\
\text { Chilostomella } \\
\text { Fissurina } \\
\text { Heronallenia }\end{array}$ & $\begin{array}{l}\text { Bulimina } \\
\text { Uvigerina }\end{array}$ & $\begin{array}{l}\text { Globocassidulina } \\
\text { Lagena } \\
\text { Pullenia bulloides }\end{array}$ \\
\hline
\end{tabular}

Table 4. Relationship of relative abundance of benthic foraminifers with lithologies (Core 138-844C-8H).

\begin{tabular}{lrlrlrl}
\hline \multicolumn{1}{c}{ Species } & $\begin{array}{c}\text { L average } \\
(\%)\end{array}$ & \multicolumn{1}{c}{$\begin{array}{c}\text { L range } \\
(\%)\end{array}$} & $\begin{array}{c}\mathrm{B} \text { average } \\
(\%)\end{array}$ & $\begin{array}{c}\mathrm{B} \text { range } \\
(\%)\end{array}$ & $\begin{array}{c}\mathrm{H} \text { average } \\
(\%)\end{array}$ & $\begin{array}{c}\mathrm{H} \text { range } \\
(\%)\end{array}$ \\
\hline A.weddellensis & 18.4 & $0.5-27.7$ & 4.6 & $6.4-29$ & 4.6 & $1.4-7.6$ \\
E. exigua & 4.0 & $0.5-6.8$ & 9.5 & $3.3-14.0$ & 14.0 & $7.1-21.0$ \\
Eponides & 7.8 & $0.0-6.8$ & 3.5 & $3.2-7.7$ & 0.5 & $0.0-2.0$ \\
Gyroidina & 23.1 & $7.7-31.8$ & 8.6 & $2.3-1.7$ & 8.5 & $6.8-13.4$ \\
Cibicides & 20.8 & $3.2-30.8$ & 12.4 & $4.8-22.4$ & 10.8 & $5.7-12.2$ \\
Globocassidulina & 1.4 & $0.0-3.8$ & 6.7 & $2.4-14.8$ & 3.1 & $0.0-4.8$ \\
Uvigerina & 0.5 & $0.0-1.1$ & 3.7 & $0.0-13.9$ & 2.8 & $0.7-6.2$ \\
Nuttallides & 4.4 & $0.8-9.1$ & $0.0-0.5$ & $0.0-0.5$ & 5.9 & $0.0-17$ \\
\hline
\end{tabular}

Note: Abbreviations as in Figure 1.

Table 5. Relationship of relative abundances of benthic foraminifer morphotypes with lithologies (Core 138-844R-8H).

\begin{tabular}{|c|c|c|c|c|c|c|}
\hline & $\begin{array}{c}\text { Laverage } \\
\text { (\%) }\end{array}$ & $\begin{array}{c}\text { L range } \\
(\%)\end{array}$ & $\begin{array}{c}\text { B average } \\
\text { (\%) }\end{array}$ & $\begin{array}{c}\text { B range } \\
(\%)\end{array}$ & $\begin{array}{c}H \text { average } \\
\text { (\%) }\end{array}$ & $\begin{array}{c}\mathrm{H} \text { range } \\
(\%)\end{array}$ \\
\hline \multicolumn{7}{|l|}{ Epifaunal } \\
\hline Round trochospiral & 22.7 & $7.7-29.7$ & 8.7 & $3.0-17.0$ & 7.7 & $4.2-11.9$ \\
\hline Planoconvex trochospiral & 18.9 & $10.9-35.3$ & 14.6 & $8.6-23.6$ & 11.2 & $9.4-13.8$ \\
\hline Milioline & 0.1 & $0.0-0.7$ & 0.5 & $0.0-1.3$ & 1.1 & $0.7-1.9$ \\
\hline Biconvex trochospiral & 35.2 & $18.6-43.8$ & 45.3 & $40.1-60.6$ & 38.2 & $23.8-45.1$ \\
\hline Total epifaunal & 82.6 & $72.9-90.1$ & 69.2 & $59.0-86.2$ & 58.3 & $49.6-67.9$ \\
\hline \multicolumn{7}{|l|}{ Infaunal forms } \\
\hline Round planisprial & 8.4 & $0.5-9.9$ & 6.5 & $0.5-9.9$ & 9.4 & $6.1-16.0$ \\
\hline Flattened ovoid & 2.8 & $1.4-5.4$ & 10.9 & $6.5-21.0$ & 10.9 & $4.5-24.7$ \\
\hline Tapered and cylindrical & 1.9 & $0.7-3.7$ & 8.6 & $3.3-17.6$ & 16.1 & $11.7-26.7$ \\
\hline Spherical & 1.9 & $0.0-4.5$ & 0.8 & $0.0-2.6$ & 0.6 & $0.0-1.4$ \\
\hline Total infaunal & 17.4 & $10.0-27.0$ & 30.2 & $14.0-41.0$ & 41.7 & $32.0-50.0$ \\
\hline
\end{tabular}

Note: Abbreviations as in Figure 1.

eneous foraminifer nannofossil ooze Eponides spp. are rare. Gyroidina spp. and Cibicides spp. have the greatest relative abundance within the laminated diatom ooze (Table 4) and decrease in relative abundance within both the bioturbated and homogeneous samples. Variations in the relative abundance of Cibicides spp. and Gyroidina spp. show a close correlation with the relative abundance of epifaunal species (Fig. 1).

The infaunal Globocassidulina spp. reach significant levels $(>10 \%)$ only within one sample of bioturbated diatom nannofossil

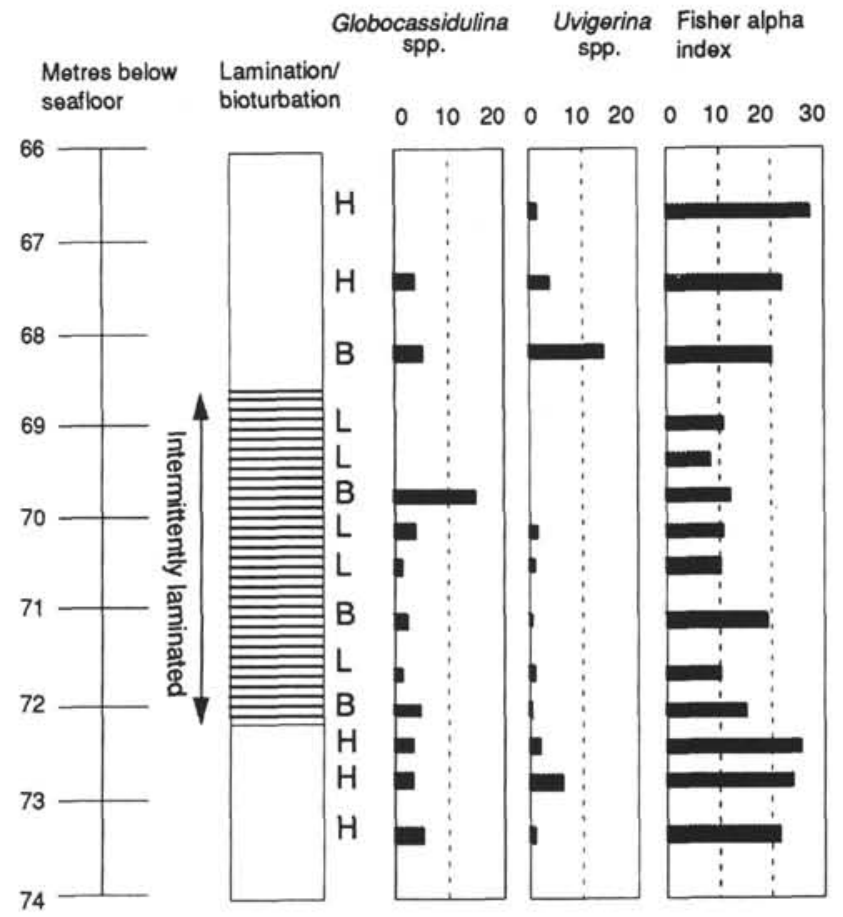

Figure 2. Hole $844 \mathrm{C}$. Relative abundances of infaunal benthic foraminifers. Abbreviations as in Figure 1.

ooze, toward the top of the intermittently laminated interval (Fig. 2). Uvigerina spp. have their lowest abundance within the intermittently laminated interval (Fig. 2). Nuttallides spp. decrease in abundance within the laminated samples. Their lowest abundance is within the bioturbated horizons.

Minor taxa recognized include Bolivinellina spp., Bulimina spp., Cassidulina spp., Laticarinina pauperata, Melonis spp., and Valvulineria laevigata (Tables 2 and 3). In total, these forms rarely make up more than $10 \%$ of the assemblage.

The species diversity decreases within the intermittently laminated section (Fig. 2). The average Fisher alpha value in the nannofossil ooze was 22.5 , while in the laminated section, it was 9.5 .

\section{Morphotypes}

The study of morphotypes provides interesting results. The infaunal tapered and cylindrical forms were much less abundant in the laminated diatom ooze (Fig. 3; Table 5). The flattened ovoid forms also are rarer in the laminated samples (Fig. 3; Table 5). Samples from the bioturbated nannofossil diatom/diatom nannofossil ooze have a similar abundance for this form with a greater range of values (Table 5).

Among the epifaunal taxa, the rounded trochospiral forms are more abundant in the laminated sediments (Fig. 3; Table 5), as are plano-convex trochospiral forms (Fig. 3). In both cases, a wide range of values occurs within the intermittently laminated interval (Table 5). Biconvex trochospiral forms are more common in the bioturbated horizons and make up on average $45 \%$ of the assemblage.

The average relative abundance of epifaunal foraminifers within the laminated diatom ooze is $83 \%$, vs. $58 \%$ in the homogeneous foraminifer nannofossil ooze and $69 \%$ within the bioturbated diatom nannofossil ooze and nannofossil diatom ooze, where the range is greater.

In summary, the following major differences in benthic foraminifer assemblages occur:

1. The assemblage within the foraminifer nannofossil ooze is more diverse than in the laminated section (Fig. 2). 


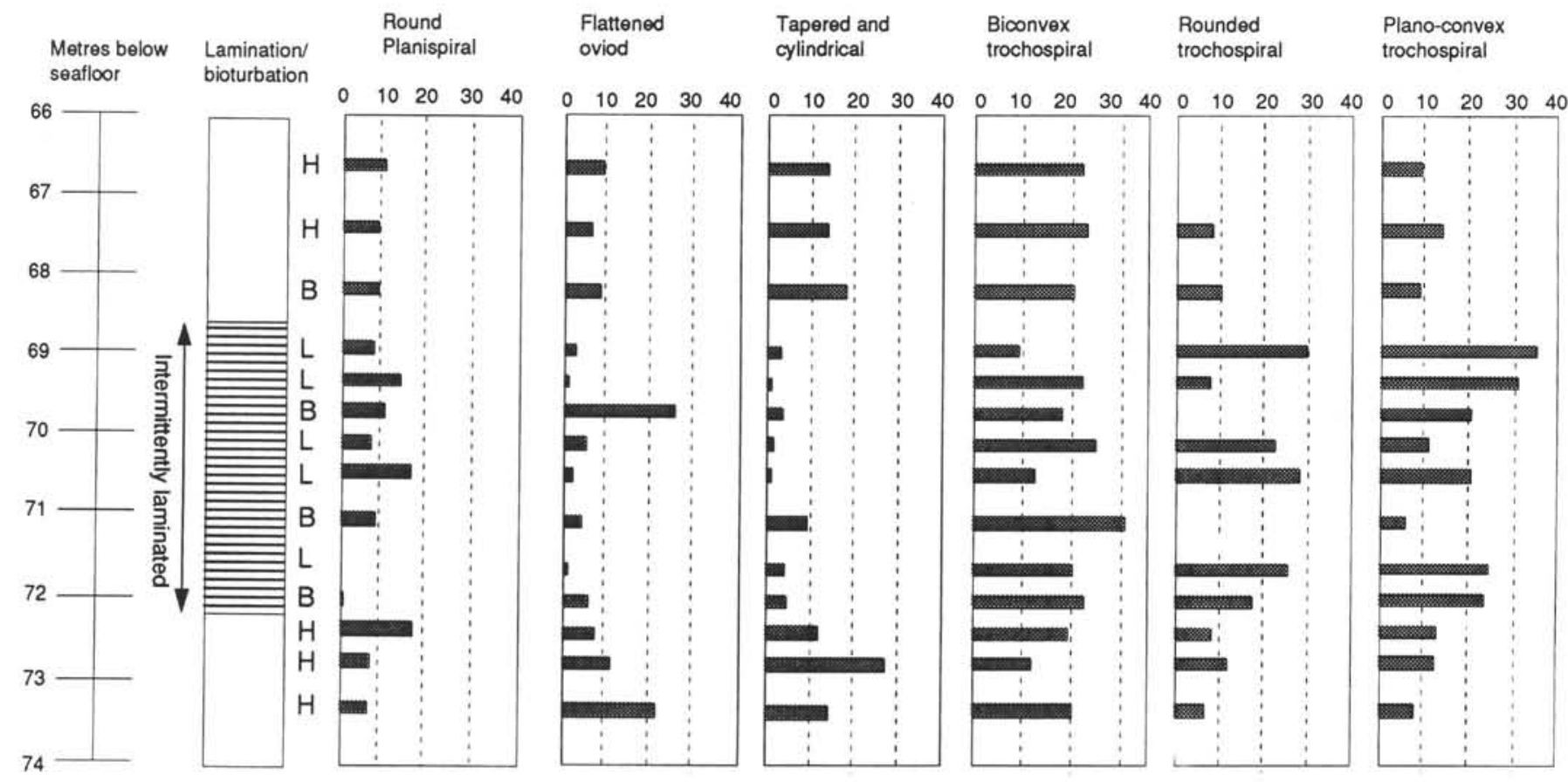

Figure 3. Hole 844C. Relative abundances of benthic foraminifers morphotypes. Abbreviations as in Figure 1.

2. Epifaunal foraminifers are more abundant in the laminated section (Fig. 2).

3. Epifaunal, trochospiral forms (with the exception of Epistominella exigua) increased in abundance within the intermittently laminated interval (Figs. 1 and 3 ).

4. Infaunal, tapered, and cylindrical forms showed a decrease in abundance through the laminated interval.

\section{DISCUSSION}

Forms that have been used as low oxygen indicators (e.g., Bolivinellina spp., Resig, 1981, 1990) do not reach significant levels at any point through the section and are not present within the laminated horizon. Forms regarded as characteristic of well-oxygenated conditions, such as Cibicides spp. and Gyroidina spp., are present throughout the section and increase in relative abundance within the laminated interval. Thus, no evidence is seen from the benthic foraminifer assemblage of any development of benthic low-oxygen conditions during diatom mat deposition.

Tapered cylindrical forms, for example Bolivinellina spp. and Uvigerina spp., decrease in abundance in the laminated section, while trochospiral forms, which include Cibicides spp. and Gyroidina spp. (Fig. 1), increase in abundance through the laminated section. The increase in relative abundance of the epifaunal, at the expense of infaunal species, and decrease in the diversity of the total assemblage suggest that habitat, shape, and mode of life are the dominant controls on the variation of foraminifer species through the laminated intervals. The diatom meshwork formed by the sequentially deposited mats was of so fine a nature (PI. 1) that it could have restricted the movement of foraminifers, especially elongated forms, through the sediment. The high tensile strength of the meshwork is shown by observations of individual mat laminations that were plucked from the core during wire cutting and of coring problems (Kemp et al., this volume).

The rapidly sedimenting diatom mats undoubtedly contained much associated organic material, so that, clearly, there was an incentive for benthic foraminifers to graze them (Gooday and Lambshead, 1989). However, the reduction in species diversity is a corollary of the abundance of a few opportunists that colonize the mat substrate. Cibicides spp. are known to be epifaunal and to live on elevated parts of the substrate (Lutze and Theil, 1989). Such microhabitats may have been common over areas of diatom mat from which bundles of the tough, long ( $5 \mu \mathrm{m}$ wide, but up to $4 \mathrm{~mm}$ long) Thalassiothrix longissima frustules protruded. Epistominella exigua has been observed with organic "fluff" material (phytodetritus) on modern sediment surfaces (Gooday and Lambshead, 1989). The Thalassiothrix mat deposits would not have provided such an open, penetrable pasture and may have inhibited the mobility of $E$. exigua.

Alabaminella weddellensis is known to correlate strongly with an influx of phytodetritus (Gooday and Lambshead, 1989), but at Site 844 little correlation was seen between $A$. weddellensis and $E$. exigua. Furthermore, A. weddellensis shows a more complex relationship with the mat deposits as it initially increases then decreases within the laminated interval (Fig. 1). This suggests that variations in the relative abundance of $A$. weddellensis may not have been controlled solely by the mat sediment, but may relate to changes in other oceanographic conditions associated with the onset of episodes of rapid mat flux.

\section{CONCLUSIONS}

From preliminary studies, the significant difference in benthic foraminifer assemblage documented between the background sediment of foraminifer nannofossil ooze and the laminated diatom mat deposits may be explained by the physical nature of the diatom mats, which may have acted to suppress infaunal benthic activity. Some indication exists for an increase in the relative abundance of epifaunal species that would have grazed on phytodetritus, but this increase is not universal and may have been restricted to species best adapted to the irregular nature of the mat surface with protruding diatom frustules. No evidence can be seen for any decrease in the benthic oxygen levels within the laminated intervals. Further work should be conducted on similar laminated sections to gauge the effect of episodes of mat flux on the benthic environment at different sites and at different age intervals.

\section{ACKNOWLEDGMENTS}

This work was conducted during tenure of a NERC research studentship and under NERC ODP Special Topic Grant GST/02/713 
(S. King). A. Kemp acknowledges support from the NERC ODP Special Topic. The authors gratefully acknowledge their discussions with E. Thomas, A. Gooday, and B. Corliss.

\section{REFERENCES}

Bandy, O.L., and Rodolfo, K.S., 1964. Distribution of foraminifera and sediments, Peru-Chile trench area. Deep-Sea Res. Part A, 11:817-837.

Boltovskoy, E., 1976. Distribution of Recent foraminifera of the South American region. In Hedley, R.H., and Adams, C.G. (Eds.), Foraminifera (Vol 2): London (Academic Press), 171-237.

Corliss, B.H., 1985. Microhabitats of benthic foraminifera within deep-sea sediments. Nature, 314:435-438.

Corliss, B.H., and Chen, C., 1988. Morphotype patterns of Norwegian Sea deep-sea benthic foraminifera and ecological implications. Geology, 16:716-719.

Corliss, B.H., Martinson, D.G., and Keffer, T., 1986. Late Quaternary deepocean circulation. Geol. Soc. Am. Bull., 97:1106-1121.

Fisher, R.A, Corbet, A.S., and Williams, C.B., 1943. The relationship between the number of species and the number of individuals in a random sample of an animal population. J. Anim. Ecol., 12:42-58.

Gooday, A.J., and Lambshead, P.J.D., 1989. Influence of seasonally deposited phytodetritus on benthic foraminiferal populations in the bathyal Atlantic: the species response. Mar. Ecol. Prog. Ser., 58:53-67.

Herguera, J.C., 1992. Deep-sea benthic foraminifers and biogenic opal: glacial to postglacial productivity changes in the western equatorial Pacific. Mar Micropaleontol., 19:79-98.

Kemp, A.E.S., and Baldauf, J.G., 1993. Vast Neogene laminated diatom mat deposits from the eastern equatorial Pacific Ocean. Nature, 362:141-144.

Lutze, G.F., and Coulbourn, W., 1984. Recent benthic foraminifera from the continental margin of Northwest Africa: community structure and distribution. Mar. Micropaleontol., 8:361-401.

Lutze, G.F., and Thiel, H., 1989. Epibenthic foraminifera from elevated microhabitats, Cibicidoides wuellerstorfi and Planulina ariminensis. J. Foraminiferal Res., 19:153-158.

Mackensen, A., and Douglas, R.G., 1989. Down-core distribution of live and dead deep-water benthic foraminifera in box cores from the Weddell Sea and California continental borderland. Deep-Sea Res. Part A, 36:879-900.

McCorkle, D.C., Keigwin, L.D., Corliss, B.H., and Emerson, S.R., 1990. The influence of microhabitats on the carbon isotopic composition of deep sea benthic foraminifera. Paleoceanography, 5:161-185.
Miller, K.G., and Lohmann, G.P., 1982. Environmental distribution of Recent benthic foraminifera on the northeast United States continental slope. Geol. Soc. Am. Bull., 93:200-206.

Mullins, H.T., Thompson, J.B., McDougall, K., and Vercoutere, T.L., 1985. Oxygen-minimum zone edge effects: evidence from the Central California coastal upwelling system. Geology, 13:491-494.

Murray, J.W., 1991. Ecology and Palaeoecology of Benthic Foraminifera: London (Longman).

Resig, J.M, 1981. Biogeography of benthic foraminifera of the northern Nazca Plate and adjacent continental margin. In Kulm, L.D., Dymond, J., Dasch, E.J., Hussong, D.M., and Roderick, R. (Eds.), Nazca Plate: Crustal Formation and Andean Convergence. Mem.-Geol. Soc. Am., 154:619666.

1990. Benthic foraminiferal stratigraphy and paleoenvironments off Peru, Leg 112. In Suess, E., von Huene, R., et al., Proc. ODP, Sci. Results, 112: College Station, TX (Ocean Drilling Program), 263-296.

Sancetta, C., Villareal, T., and Falkowski, P., 1991. Massive fluxes of rhizosolenid diatoms: a common occurrence? Limnol. Oceanogr., 36:1452-1457.

Smith, K.L., Baldwin, R.J., and Williams, P.M., 1992. Reconciling particulate organic carbon flux and sediment community oxygen consumption in the deep North Pacific. Nature, 359:313-316.

Streeter, S.S., and Shackleton, N.J., 1979. Paleocirculation of the deep North Atlantic: 150,000 year record of benthic foraminifera and oxygen-18. Science, 203:168-171.

Thomas, E., 1985. Late Eocene to Recent deep-sea benthic foraminifers from the central equatorial Pacific Ocean. In Mayer, L., Theyer, F., Thomas, E., et al., Init. Repts. DSDP, 85: Washington (U.S. Govt. Printing Office), $655-694$.

Woodruff, F., and Savin, S.M., 1985. $\delta^{13} \mathrm{C}$ values of Miocene Pacific benthic foraminifera: correlations with sea level and biological productivity. Geology, 13:119-12

\footnotetext{
Abbreviations for names of organizations and publication titles in ODP reference lists follow the style given in Chemical Abstracts Service Source Index (published by American Chemical Society).
}

\author{
Date of initial receipt: 9 February 1993 \\ Date of acceptance: 28 December 1993 \\ Ms 138SR-137
}


APPENDIX A

Relative Abundances of Benthic Foraminifers and Total Numbers Counted (Core 138-844C-8H).

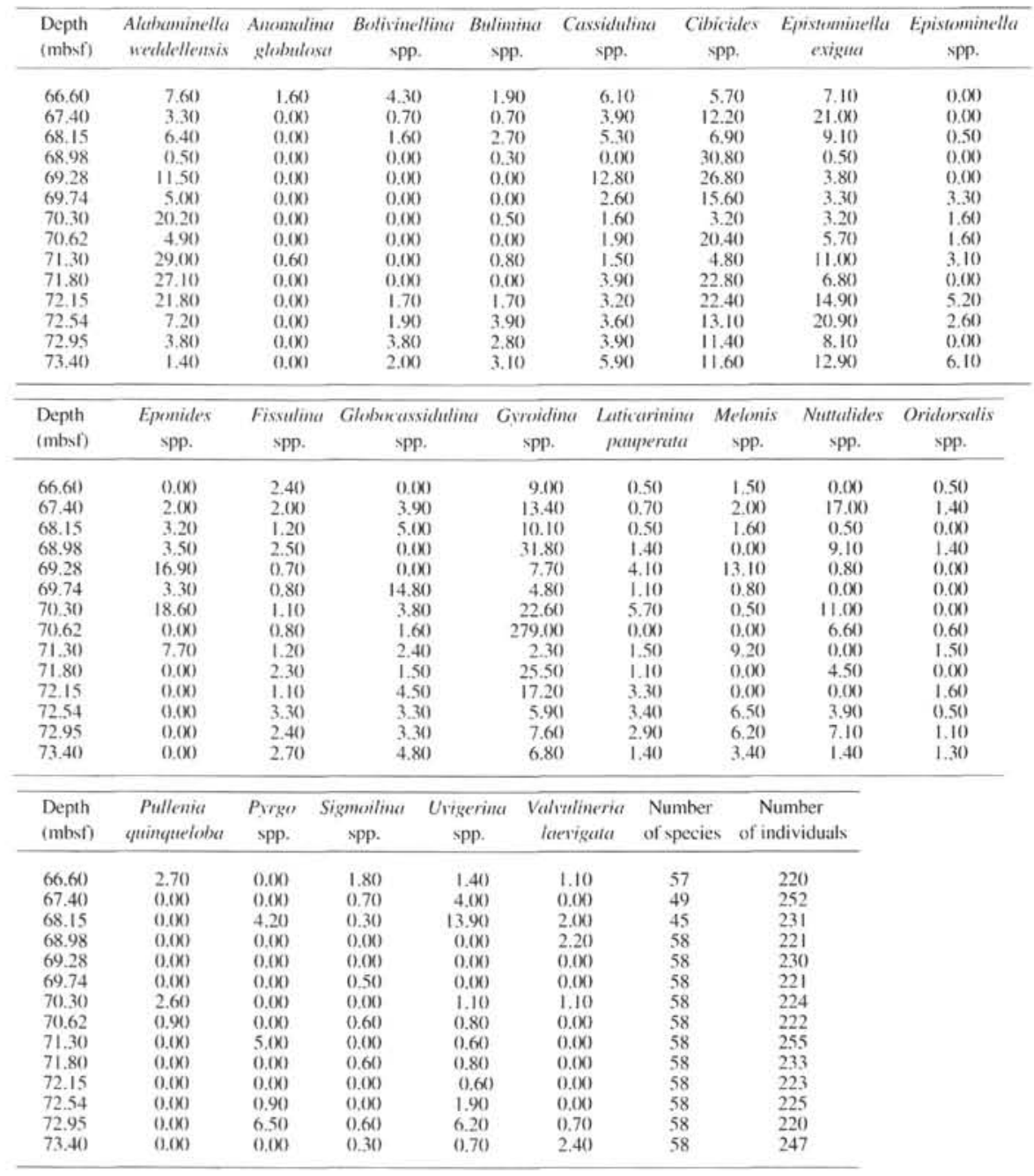


APPENDIX B

Relative Abundance of Benthic Foraminifer Morphotypes (Core 138-844C-8H).

\begin{tabular}{lrcccccccc}
\hline $\begin{array}{c}\text { Depth } \\
\text { (mbsf) }\end{array}$ & $\begin{array}{c}\text { Round } \\
\text { trochospiral }\end{array}$ & Milioline & $\begin{array}{c}\text { Planoconvex } \\
\text { trochospiral }\end{array}$ & $\begin{array}{c}\text { Biconvex } \\
\text { trochospiral }\end{array}$ & $\begin{array}{c}\text { Round } \\
\text { planispiral }\end{array}$ & $\begin{array}{c}\text { Flattened } \\
\text { ovoid }\end{array}$ & $\begin{array}{c}\text { Tapered and } \\
\text { cylindrical }\end{array}$ & $\begin{array}{c}\text { Total } \\
\text { Spherical } \\
\text { epifaunal }\end{array}$ \\
\hline 66.60 & 4.20 & 1.90 & 9.50 & 43.10 & 9.90 & 9.00 & 13.70 & 0.00 & 58.70 \\
67.40 & 8.00 & 0.70 & 13.80 & 45.40 & 7.90 & 6.60 & 13.80 & 0.00 & 67.90 \\
68.15 & 10.00 & 0.30 & 8.60 & 40.10 & 8.00 & 8.60 & 17.60 & 0.00 & 59.10 \\
68.98 & 29.80 & 0.00 & 35.60 & 18.70 & 7.10 & 3.00 & 3.00 & 4.50 & 83.82 \\
69.28 & 7.70 & 0.70 & 31.40 & 43.80 & 13.10 & 1.40 & 0.70 & 0.00 & 83.60 \\
69.74 & 4.80 & 0.00 & 20.70 & 35.50 & 9.90 & 24.80 & 3.30 & 0.00 & 61.00 \\
70.30 & 22.60 & 0.00 & 10.93 & 49.20 & 6.60 & 5.40 & 1.60 & 4.40 & 82.70 \\
70.62 & 27.90 & 0.00 & 20.40 & 24.60 & 15.60 & 2.50 & 0.80 & 0.80 & 72.90 \\
71.30 & 3.00 & 1.20 & 5.81 & 60.60 & 7.70 & 4.50 & 9.00 & 2.60 & 70.60 \\
71.80 & 25.50 & 0.00 & 24.80 & 39.80 & 0.00 & 1.50 & 3.80 & 0.00 & 90.10 \\
72.15 & 17.30 & 0.57 & 24.60 & 44.80 & 0.60 & 5.70 & 4.60 & 0.60 & 86.20 \\
72.54 & 7.90 & 0.65 & 13.10 & 38.60 & 16.50 & 7.20 & 11.80 & 0.70 & 60.20 \\
72.95 & 11.90 & 1.40 & 12.42 & 23.80 & 6.80 & 10.90 & 26.80 & 1.40 & 49.59 \\
73.40 & 6.80 & 0.68 & 7.84 & 40.10 & 6.10 & 21.10 & 14.30 & 1.00 & 55.10
\end{tabular}

APPENDIX C

\section{Faunal Reference List}

Alabaminella weddellensis (Earland) $=$ Eponides weddellensis Earland, 1936

Anomalina globulosa Chapman and Parr, 1937

Epistominella exigua $($ Brandy $)=$ Pulvinalina exigua Brady, 1844

Laticarinina pauperata $($ Parker and Jones) $=$ Pulvinulina repanda var. pauperata Parker and Jones, 1865

Oridorsalis umbonatus (Reuss) $=$ Rotalina umbonatus Ruess, 1851

Pullenia bulloides (d'Orbigny) = Nonionina bulloides d'Orbigny, 1846

Pullenia quinqueloba (Reuss) $=$ Nonionina quinqueloba Reuss, 1851 


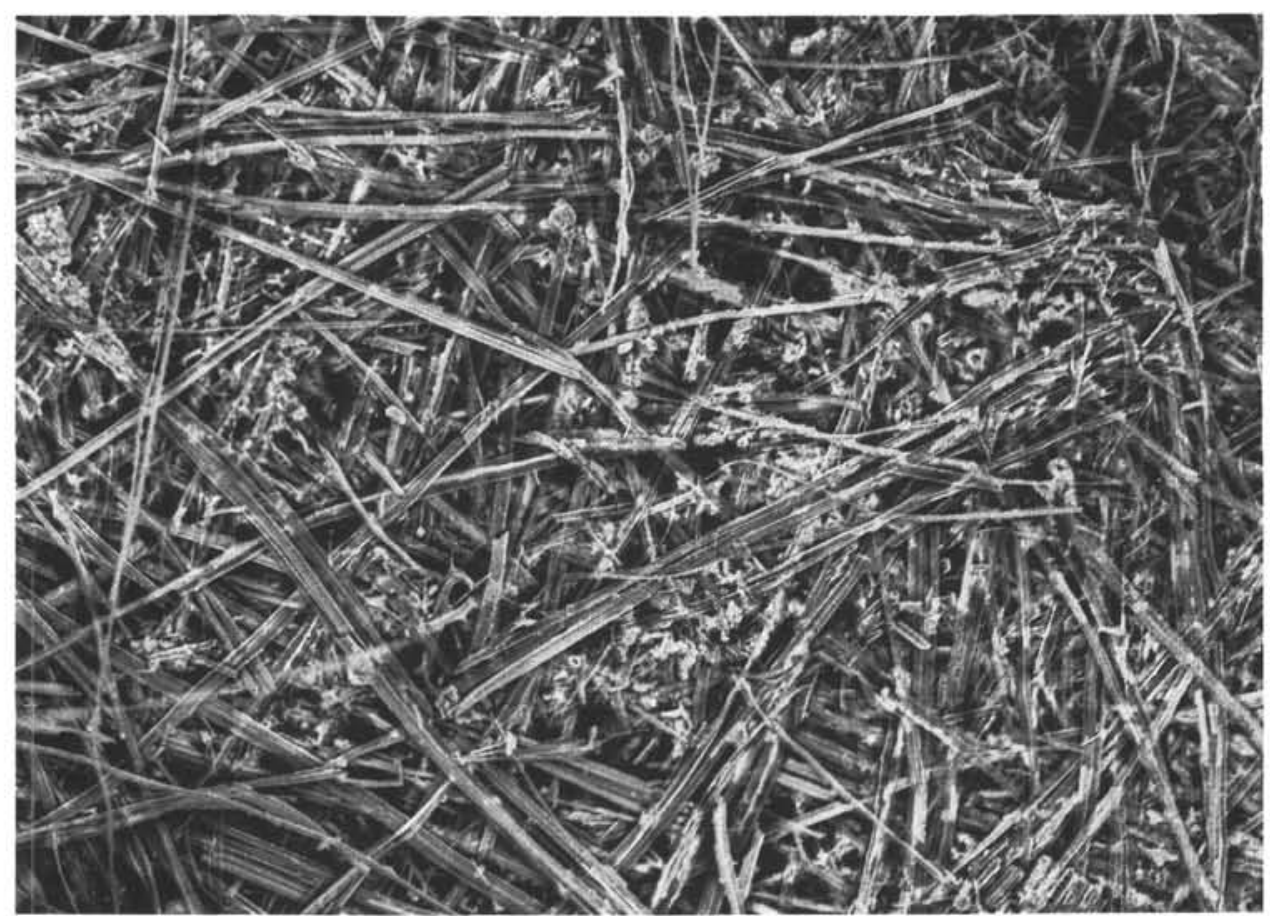

Plate 1. Scanning electron microscope image of diatom mat deposit. Back scatter electron (topographic) image showing the surface of a peeled $T$. longissima-rich lamina. 


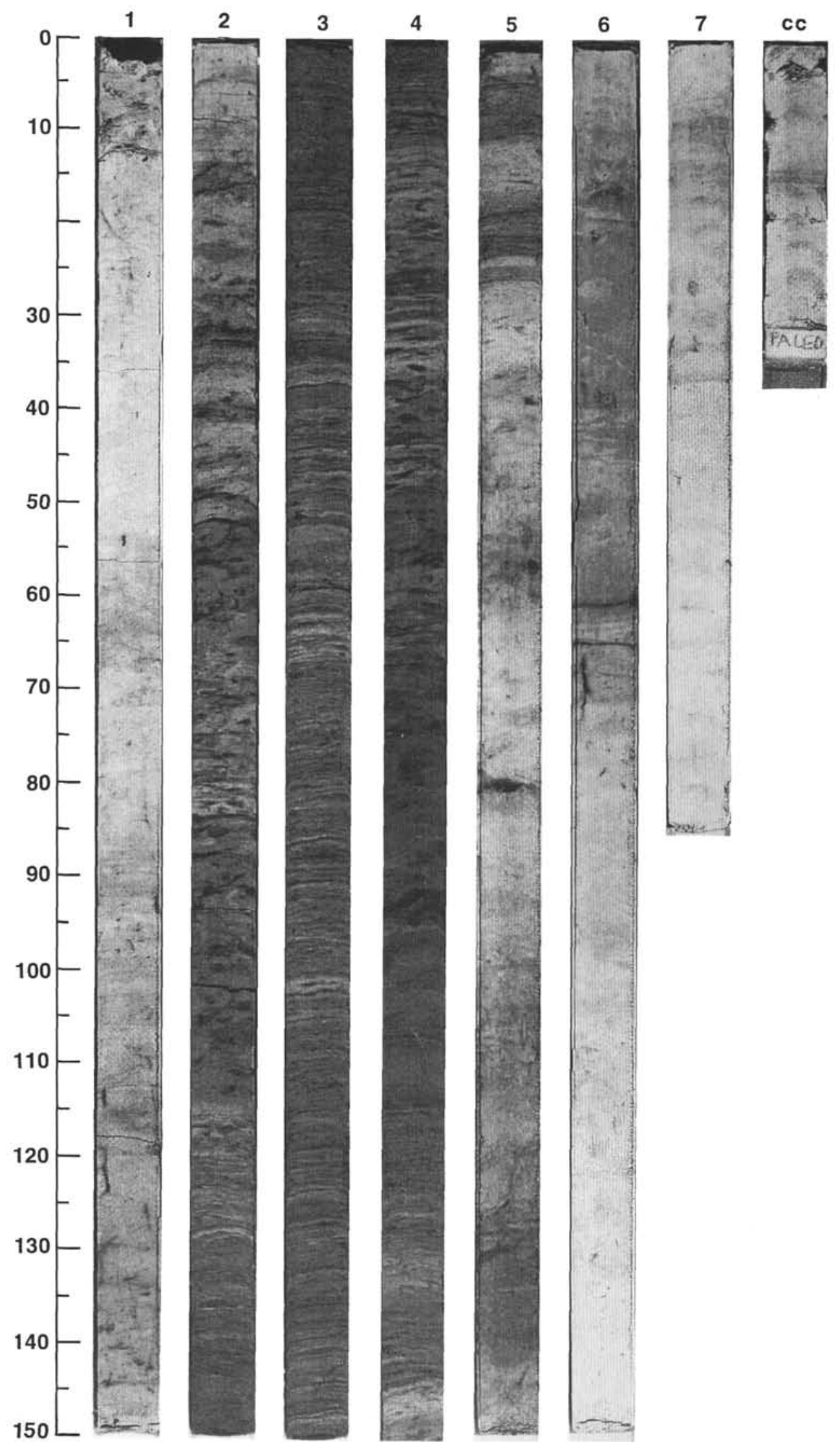

Plate 2. Core 138-844C-8H; solid circles indicate points sampled. Diatom-rich laminated sections are dark with uneven surfaces. 